\title{
Biological effects of extracts obtained from Stryphnodendron adstringens on Herpetomonas samuelpessoai
}

\author{
Fabíola Barbieri Holetz / + , Tânia Ueda-Nakamura*, Benedito Prado Dias Filho*, \\ João Carlos Palazzo de Mello**, José Andrés Morgado-Díaz***, \\ Cleyton Eduardo Mendes de Toledo**, Celso Vataru Nakamura*/+
}

Programa de Pós-graduação em Ciências Farmacêuticas *Departamento de Análises Clínicas **Departamento de Farmácia e Farmacologia, Universidade Estadual de Maringá, Av. Colombo 5790, 87020-900 Maringá, PR, Brasil ***Divisão de Biologia Celular, Instituto Nacional de Câncer, Rio de Janeiro, RJ, Brasil

We report the effect of Stryphnodendron adstringens on the trypanosomatid Herpetomonas samuelpessoai. The parasites were grown at $28^{\circ} \mathrm{C}$ in a chemically defined medium containing crude extract and fractions at concentrations from 100 to $5000 \mu \mathrm{g} / \mathrm{ml}$ obtained from S. adstringens. Concentrations of 500, 1000, 2500, and $5000 \mu \mathrm{g} / \mathrm{ml} \mathrm{both}$ crude extract and semi-purified fraction progressively inhibited the protozoans' growth. At a concentration of 100 $\mu \mathrm{g} / \mathrm{ml}$, crude extract or a semi-purified (F3) fraction did not affect the growth of the protozoans. The F3-9 - F3-12 sub-fractions, at a concentration of $1000 \mu \mathrm{g} / \mathrm{ml}$, also showed increased inhibitory activity on $\mathrm{H}$. samuelpessoai. The $I C_{50}$ of the crude extract and the F3 fraction were 538 and $634 \mu \mathrm{g} / \mathrm{ml}$, respectively. Ultrastructural and enzymatic alterations in the trypanosomatids were also evaluated. $\mathrm{H}$. samuelpessoai cultivated in the presence of $I C_{50}$ crude extract showed considerable ultrastructural alterations, such as marked mitochondrial swelling with a large number of cristae and evident Golgi complex vesiculation, as observed by transmission electron microscopy. Cells exposed to $538 \mu \mathrm{g} / \mathrm{ml}$ of crude extract at $28^{\circ} \mathrm{C}$ for $72 \mathrm{~h}$, showed decreased activity of the enzyme succinate cytochrome c reductase, a typical mitochondrion marker, as compared to untreated cells

Key words: Herpetomonas samuelpessoai - Stryphnodendron adstringens - ultrastructural alteration - antiprotozoan activity

Stryphnodendron adstringens (Mart.) Coville (Leguminosae), commonly known as "barbatimão", is a medicinal plant widely distributed in the savannah region of Brazil (Felfili et al. 1999). The stem bark of this plant contains a considerable amount of tannin (10-37\%) and prominent presence of several flavan-3-ols, proanthocyanidins, and prorobinetinidins (Teixeira et al. 1990, Mello et al. 1996a, b). The crude extract, in the form of decoction or infusion, is traditionally used by the local population for the treatment of leucorrhoea and diarrhea, as well as an anti-inflammatory and healing agent (Santos et al. 1987, Mello et al. 1996a). Some studies of the crude extract from the stem bark of $S$. adstringens have revealed significant anti-inflammatory activity and gastric anti-ulcerogenic effects (Lima et al. 1998, Audi et al. 1999). It has also been observed that a decoction of the stem bark of $S$. barbatiman (syn. S. adstringens) accelerates the healing of wounds and decreases inflammation (Panizza et al. 1988). Crude extracts from the bark of S. adstringens have been tested for antiparasitic activity against the causative agent of Chagas disease, Trypanosoma cruzi (HerzogSoares et al. 2002).

Financial support: CNPq, Capes, Programa de Pós-Graduação em Ciências Farmacêuticas, Universidade Estadual de Maringá ${ }^{+}$Corresponding author. E-mail: cvnakamura@uem.br

${ }^{++}$Capes fellowship

Received 27 January 2005

Accepted 4 May 2005
Previous studies have shown that the crude extract of "barbatimão" has an inhibitory activity on the growth of Herpetomonas samuelpessoai (Endo et al. 2000, Holetz et al. 2002), a non-pathogenic trypanosomatid isolated from the predatory insect Zelus leucogrammus (Hemiptera: Reduviidae) (Galvão et al. 1970). This protozoan can be cultivated in synthetic medium (Roitman et al. 1972), is sensitive to some drugs active against $T$. cruzi (Roitman \& Roitman 1972), and has been used as a model to study the biology of trypanosomatids by several research groups in Brazil. Thus, H. samuelpessoai may be suitable as a model for screening new trypanocidal drugs.

In view of the therapeutic activity of crude extracts of $S$. adstringens, which justifies the extensive use of this plant in Brazilian folk medicine, the present study was undertaken to investigate the influence of the crude extract and fractions of "barbatimão" on morphological and biochemical alterations in $H$. samuelpessoai.

\section{MATERIALS AND METHODS}

Preparation of crude plant extract and fractionation - S. adstringens bark was collected during November 1999 from São Jerônimo da Serra, state of Paraná, Brazil. A voucher herbarium specimen was deposited under number HUM 3800 in the Herbarium of the State University of Maringá, Paraná, Brazil.

The bark (120 g) was dried in the dark at room temperature, powdered, and extracted by turbo-extraction in $70 \%$ acetone. Afterwards, the crude acetonic extract was evaporated under reduced pressure to yield the residue F1 $(50 \mathrm{~g})$. The active crude extract was re-dissolved in water and partitioned with ethyl-acetate to obtain the water-soluble fraction (F2) and the ethyl-acetate-soluble 
fraction (F3). The fraction F3 (20 g) was subjected to column chromatography on Sephade ${ }^{\circledR}$ LH-20 with a gradient of ethanol-water 1:1, ethanol (100\%), and acetonewater 7:3. Twelve sub-fractions (F3-1 - F3-12) were collected, concentrated in vacuum, and freeze-dried.

Microbial culture growth conditions and antiprotozoal activity - H. samuelpessoai (ATCC 30252) was grown in a chemically defined medium at $28^{\circ} \mathrm{C}$ for $48 \mathrm{~h}$ and maintained at $4^{\circ} \mathrm{C}$. Protozoans in the logarithmic growth phase, at a concentration of $10^{6} \mathrm{cells} / \mathrm{ml}$, were incubated in defined medium in the presence of 100,500,1000,2500, and $5000 \mu \mathrm{g} / \mathrm{ml}$ of crude extract or F3 fraction, and 1000 $\mu \mathrm{g} / \mathrm{ml}$ of sub-fractions F3-1 - F3-12, which were added only once to the cultures. After $24,48,72$, and $96 \mathrm{~h}$ at $28^{\circ} \mathrm{C}$, cell growth was estimated by counting in a Neubauer's chamber. All experiments were performed in triplicate. The $\mathrm{IC}_{50}$ values were determined by linear regression analysis from this inhibition percentage using statistic error limits up $10 \%$.

Ultrastructural analysis - In order to analyse the influence of "barbatimão" on the ultrastructure of the protozoans, the cells were treated with $538 \mu \mathrm{g} / \mathrm{ml}$ of crude extract for $72 \mathrm{~h}$ at $28^{\circ} \mathrm{C}$, washed in PBS pH 7.2 0.01 M, and fixed with $2.5 \%$ glutaraldehyde in $0.1 \mathrm{M}$ sodium cacodylate buffer at $4^{\circ} \mathrm{C}$. The cells were washed three times with $0.1 \mathrm{M}$ sodium cacodylate buffer, and postfixation was performed in $1 \%$ osmium tetroxide plus $0.8 \%$ potassium ferrocyanide and $5 \mathrm{mM}$ calcium chloride for $30 \mathrm{~min}$ at room temperature in the dark. After postfixation, the samples were dehydrated in acetone and embedded in Epon. Sections (60-80 nm thick) were cut using a Reichert Ultracut E ultramicrotome with a diamond knife, and ribbons were collected on copper grids. After drying, the grids were stained with $5 \%(\mathrm{w} / \mathrm{v})$ aqueous uranyl acetate and lead citrate, and ultrathin sections were observed in a Zeiss CEM - 900 electron microscope.

Biochemical analysis - Untreated and treated cells (with $538 \mu \mathrm{g} / \mathrm{ml}$ of crude extract of S. adstringens) were incubated at $28^{\circ} \mathrm{C}$ for $72 \mathrm{~h}$, and harvested by centrifugation in a Sorvall Super 21 (SL50T Rotor) refrigerated ultracentrifuge at $1000 \mathrm{~g}$ for $10 \mathrm{~min}$. The cells were then washed three times in phosphate buffer saline (PBS) pH 7.2, resuspended in a hypotonic solution (Tris- $\mathrm{HCl} 10 \mathrm{mM}$ ) containing a cocktail of protease inhibitors (antipain, aprotinin, leupeptin, and pepstatin: $10 \mu \mathrm{g} / \mathrm{ml}$ of each), and disrupted by sonication on ice with 20 cycles of $2 \mathrm{~s}$ with $1 \mathrm{~s}$ rest between cycles in an Ultrasonic Processor (CV 33 Model). The cell disruption was monitored with a light microscope in order to avoid damage to the nuclei. The amount of cell-free extract used in individual experiments corresponded to $200 \mu \mathrm{g}$ protein. The protein concentration was determined by a Bio-Rad protein assay kit, using bovine serum albumin as a standard and following the manufacturer's instructions.

Succinate cytochrome $c$ reductase activity was measured according to Morgado-Díaz et al. (2001). The reaction mixture contained $0.2 \mathrm{M}$ phosphate buffer $\mathrm{pH}$ 7.4; $0.003 \mathrm{M}$ EDTA $\mathrm{pH} 7.4 ; 0.6 \mathrm{M}$ succinic acid adjusted to $\mathrm{pH}$ 7.4 with $\mathrm{NaOH} ; 0.001 \mathrm{M}$ cytochrome $c$. The specific activ- ity was measured at $30^{\circ} \mathrm{C}$, by following the reduction of cytochrome $c$ at $550 \mathrm{~nm}$ and expressed as reduced cytochrome $c$ (nanomol)/min/mg protein.

\section{RESULTS AND DISCUSSION}

S. adstringens had a marked effect on the growth of $H$. samuelpessoai. Preliminary observations indicated that this protozoan displayed a similar behavior when it was submitted to different concentrations of crude extract, F2, or F3 fractions in defined medium. Fig. 1 shows the effects of F3 (ethyl-acetate-soluble fraction) on the growth of $H$. samuelpessoai incubated at $28^{\circ} \mathrm{C}$. Growth of the protozoans was not affected at a concentration of $100 \mu \mathrm{g} / \mathrm{ml}$; however, when they were cultivated for $72 \mathrm{~h}$ at concentrations of $500,1000,2500$, and $5000 \mu \mathrm{g} / \mathrm{ml}$, growth inhibition was $42,70.8,99.5$, and $99.6 \%$, respectively. The $50 \%$ inhibitory concentrations $\left(\mathrm{IC}_{50}\right)$ of the crude extract and the $\mathrm{F} 3$ fraction were 538 and $634 \mu \mathrm{g} / \mathrm{ml}$, respectively.

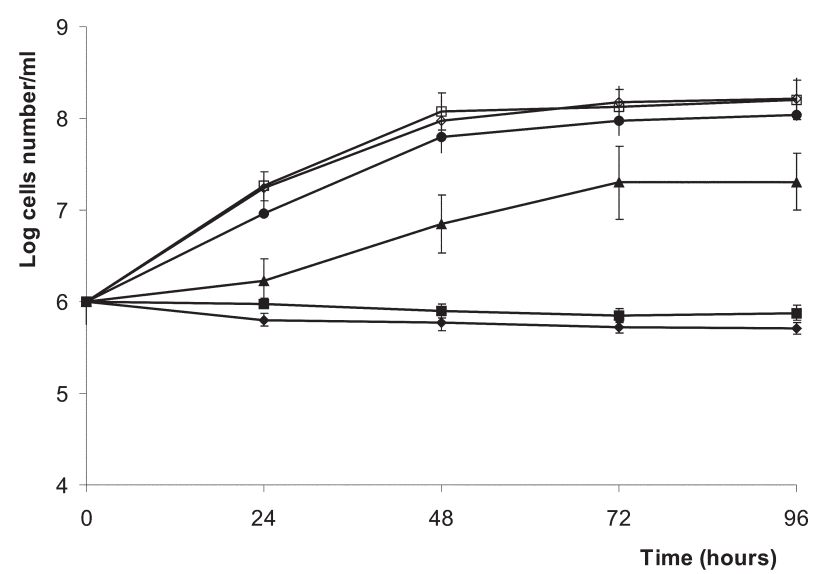

Fig. 1: effect of Stryphnodendron adstringens on the growth of Herpetomonas samuelpessoai. Parasites were incubated in defined medium in the presence of increasing concentrations of F3 fraction for $96 \mathrm{~h}$ at $28^{\circ} \mathrm{C}$. The cells were counted daily. $\diamond$ control; $\square 100 \mu \mathrm{g} /$ $\mathrm{ml} ; 500 \mu \mathrm{g} / \mathrm{ml} ; \boldsymbol{\Delta} 1000 \mu \mathrm{g} / \mathrm{ml}$ - $2500 \mu \mathrm{g} / \mathrm{ml} ; 5000 \mu \mathrm{g} / \mathrm{ml}$. The values presented are means \pm S.D. and one representative of at least three independent experiments.

Additionally, the effect of the twelve F3 sub-fractions (F3-1 - F3-12) on the growth of the protozoans, after $72 \mathrm{~h}$ incubation at $28^{\circ} \mathrm{C}$ was evaluated. Interestingly, the F3.9 F3.12 sub-fractions showed the highest activity at 1000 $\mu \mathrm{g} / \mathrm{ml}$ with $88.6 \%$ growth inhibition, when compared with the sub-fractions F3.1 - F3.4 and F3.5 - F3.8, which showed $59.7 \%$ and $70.1 \%$ growth inhibition, respectively (Fig. 2). Toledo (2002) analyzed these sub-fractions by TLC on silica gel. The chromatogram sprayed with $1 \%$ iron chloride and vanillin/sulphuric acid solutions revealed the presence of condensed tannins in the sub-fractions. It is possible that compounds of high molecular weight (oligomers, polymers) are present in the F3.9 - F3.12 sub-fractions, because condensed tannins are usually isolated in a Sephade ${ }^{\circledR}$ LH-20 column eluting first the monomeric, and next the di-, tri-, and oligomeric flavan-3-ols compounds (Thompson et al. 1972, Toledo 2002). Thus, the inhibitory activity of these sub-fractions on the protozo- 


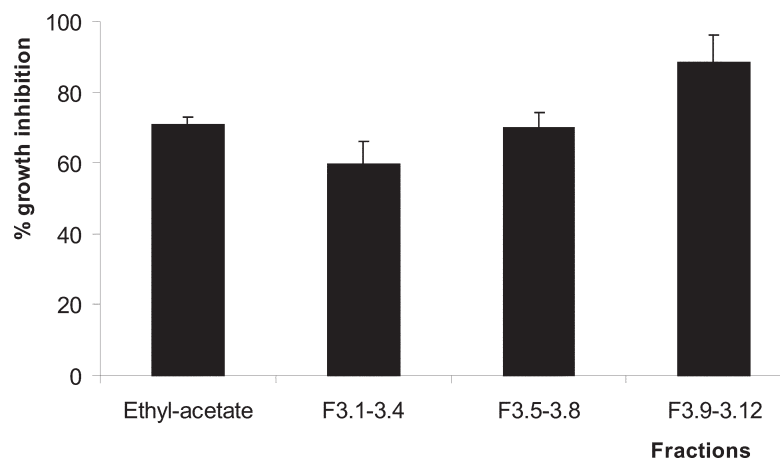

Fig. 2: effects of $1000 \mu \mathrm{g} / \mathrm{ml}$ of the ethyl-acetate fraction and the F3.1 - 3.4, F3.5 - 3.8, and F3.9 - 3.12 sub-fractions on growth of Herpetomonas samuelpessoai cultivated in defined medium at $28^{\circ} \mathrm{C}$ for $72 \mathrm{~h}$. The results are expressed as means \pm standard deviations $(\mathrm{n}=3)$.
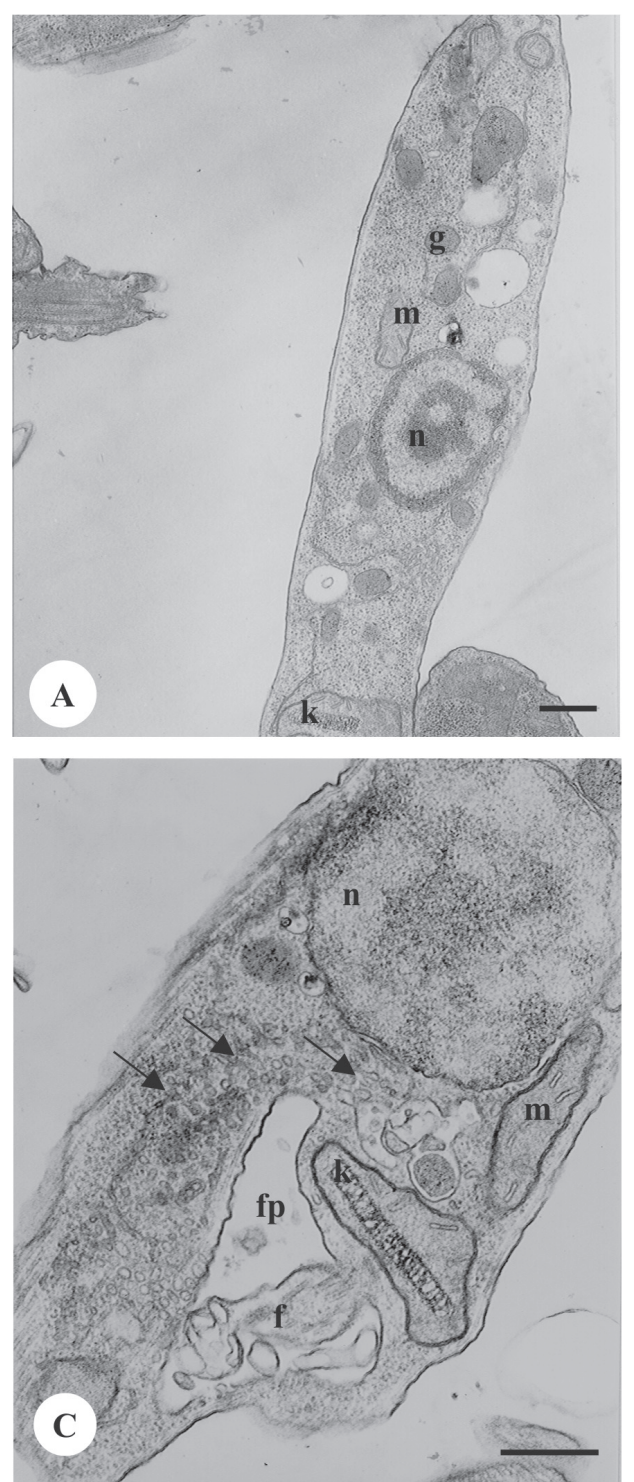

ans may be due to the action of the compounds isolated during the purification process. Another factor that might affect the process of elevated activity of the F3-9 - F3-12 sub-fractions, may be related to the stereochemistry of the substances present in these sub-fractions. It is known that condensed tannins of high molecular weight are highly hydroxylated molecules that assume different spatial conformations, which could interact in several ways with the membrane enzymes, substrate or ions of $H$. samuelpessoai. According to the Brazilian Pharmacopoeia (Farmacopéia 2002), the bark of S. adstringens contains at least $20 \%$ tannins. Mello et al. (1996a, b) and Santos et al. (2002) investigated the chemical composition of this species and established that the pharmacological activity is mainly due to the content of tannins present in the bark. A study by Scalbert (1991) established the toxicity of tannin to
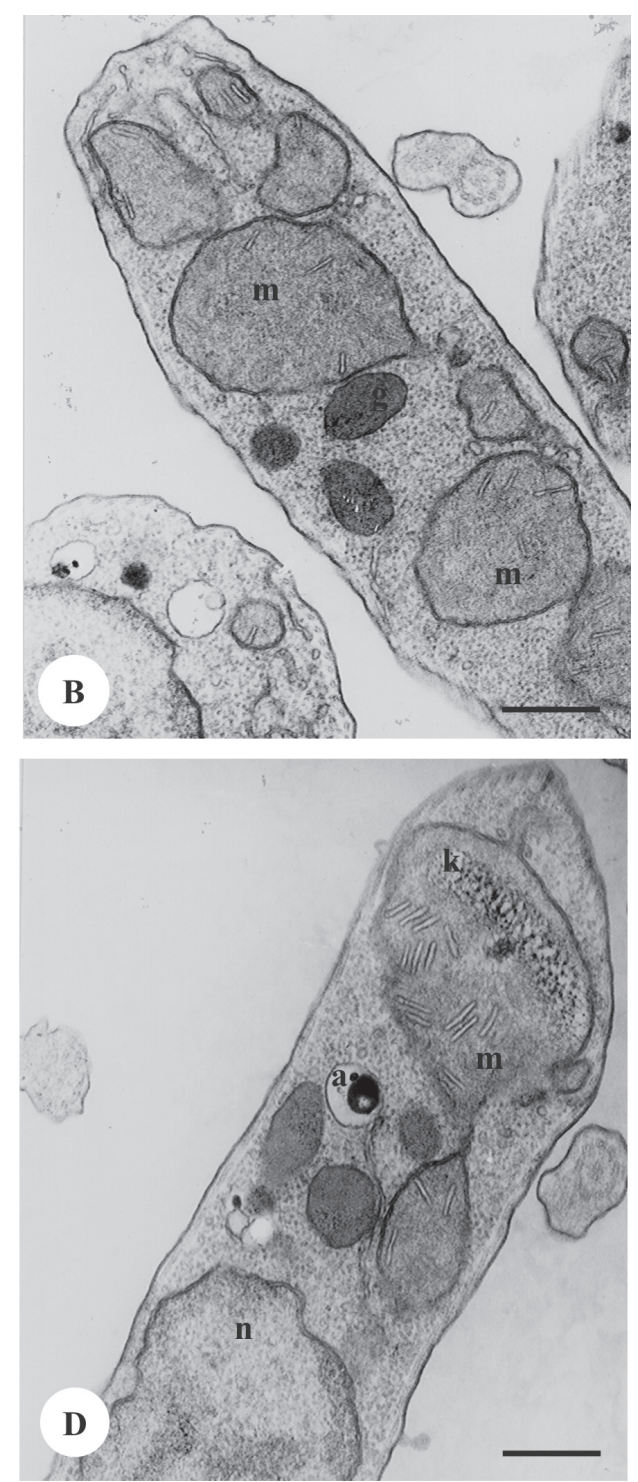

Fig. 3: transmission electron microscopy of Herpetomonas samuelpessoai grown in defined medium at $28^{\circ} \mathrm{C}$. A: general view of an untreated promastigote form of $H$. samuelpessoai, showing the nucleus $(\mathrm{n})$, the kinetoplast $(\mathrm{k})$, the glycosome $(\mathrm{g})$, and the mitochondrion; $\mathrm{B}, \mathrm{C}$, and D: promastigote treated with $538 \mu \mathrm{g} / \mathrm{ml}$ of crude extract from Stryphnodendron adstringens for $72 \mathrm{~h}$. Note mitochondrial swelling and cytoplasmic vesicles (arrows) - f: flagellum; fp: flagellar pocket; g: glycosome; k: kinetoplast; m: mitochondrion; n: nucleus. Bars $=1 \mu \mathrm{m}$ 
bacteria, filamentous fungus, and yeast. Three hypotheses might explain the antimicrobial mechanism of the tannins: (a) inhibition of enzyme activity by complexating with the substrate of bacteria and fungus; (b) direct action of the tannins on the microorganisms' metabolism, through the inhibition of oxidative phosphorylation; (c) a mechanism involving the complexation of tannins with metallic ions, decreasing the availability of essential ions to the metabolism of the microorganisms (Scalbert 1991, Santos \& Mello 2003). Taking these considerations together, our results suggest that the tannins may be the substances responsible for inhibiting the growth of $H$. samuelpessoai.

Based on these results, we selected the crude extract to continue our biochemical and microscopic tests, because it showed the lowest $\mathrm{IC}_{50}$. Therefore, the ultrastructural aspects of this protozoan were evaluated. Transmission electron microscopy of $H$. samuelpessoai exposed to "barbatimão" for $72 \mathrm{~h}$ revealed marked mitochondrial swelling and a large number of cristae, with a loss of cristae patterns (Fig. 3B, D) compared to untreated cells, which had mitochondria with well-defined membranes and a dense matrix (Fig. 3A). Also, treated cells exhibited an evident Golgi complex vesiculation (Fig. 3C).

The activity of the enzyme succinate cytochrome $c$ reductase, a well-known mitochondrial marker related to mitochondrial metabolism involved in the respiratory sequence of this flagellate, was also observed. Cells cultivated in defined medium in the presence of the crude extract of $S$. adstringens at $28^{\circ} \mathrm{C}$ for $72 \mathrm{~h}$ showed a decrease in the activity of this enzyme. The specific activity of the treated cells was $5.6 \pm 1.03 \mathrm{nanomol} / \mathrm{min} / \mathrm{mg}$ of protein, whereas in the untreated cells it was $9.7 \pm 1.82$ nanomol/ $\mathrm{min} / \mathrm{mg}$ of protein. Inhibition of this enzyme can influence the respiratory sequence, affecting mitochondrial function. This observation suggests an alteration in the production of adenosine-triphosphate (ATP), thus influencing the active transport of ions and molecules as well as alterations in the synthesis of macromolecules. In this regard Rebecca et al. (2003) demonstrated the action of a crude extract of "barbatimão" on hepatic energy metabolism, using isolated mitochondria and perfused rat liver. Their results indicated that the "barbatimão" extract impairs hepatic energy metabolism by uncoupling oxidative phosphorylation, inhibiting mitochondrial electron transport, and inhibiting ATP-synthase in isolated mitochondria. Inhibition of the electron flow in the respiratory sequence was confirmed by the gradual inhibition of the activity of the enzymes oxidase succinate and NADHoxidase in disrupted mitochondria.

The results obtained in this work demonstrated that the crude extract and fractions of "barbatimão" have a dose-dependent inhibitory effect on the growth of $H$. samuelpessoai, and alter certain biochemical and ultrastructural aspects of this protozoan. Because H. samuelpessoai is a non-pathogenic protozoan belonging to the family Trypanosomatidae, which includes the species T. cruzi and Leishmania sp., it is an excellent model system for testing new anti-protozoal drugs. The potential of $S$. adstringens as a source of new therapeutic agents against protozoans shows promise for curing protozoancaused diseases.

\section{REFERENCES}

Audi EA, Toledo DP, Peres PG, Kimura E, Pereira WK, Mello JCP, Nakamura CV, Alves-do-Prado W, Cuman RKN, Bersani-Amado CA 1999. Gastric antiulcerogenic effects of Stryphnodendron adstringens in rats. Phytotherapy Res 13: 264-266.

Endo EH, Mesquita AC, Dias Filho BP, Abreu Filho BA, UedaNakamura T, Nakamura CV 2000. Effect of crude extract of "barbatimão" (Stryphnodendron adstringens) on growth and cell differentiation of Herpetomonas samuelpessoai. In XXVII Annual Meeting on Basic Research in Chagas Disease, XVI Meeting of the Brazilian Society of Protozoology, Caxambu, MG. Mem Inst Oswaldo Cruz 95(Suppl. II): 133.

Farmacopéia Brasileira 2002. Parte II, $4^{\circ}$ fascículo, Barbatimão Barbadetimani cortex, Monografia 176, $4^{\mathrm{a}}$ ed., Atheneu, São Paulo.

Felfili JM, Silva Júnior MC, Dias BJ, Rezende AV 1999. Estudo fenológico de Stryphnodendron adstringens (Mart.) Coville no cerrado sensu stricto da Fazenda Água Limpa no Distrito Federal, Brasil. Rev Bras Botânica 22: 83-90.

Galvão AB, Oliveira RL, Carvalho ALM, Veiga GP 1970. Leptomonas pessoai sp. n. (Trypanosomatidae, Kinetoplastida, Protozoa). Rev Goiana Med 16: 229-236.

Herzog-Soares JDA, Alves R, Isac E, Bezerra JC, Gomes MH, Santos SC, Ferri PH 2002. Atividade tripanocida in vivo de Stryphnodendron adstringens (barbatimão verdadeiro) e Caryocar brasiliensis (pequi). Rev Bras Farmacol 12 (Suppl. 1): 1-2.

Holetz FB, Ueda-Nakamura T, Dias-Filho BP, Cortez DAG, Mello JCP, Nakamura CV 2002. Effect of plant extracts used in folk medicine on cell growth and differentiation of Herpetomonas samuelpessoai (Kinetoplastida, Trypanosomatidae) cultivated in defined medium. Acta Scientiarum 24: 657-662.

Lima JCS, Martins DTO, De Souza PT 1998. Experimental evaluation of stem bark of Stryphnodendron adstringens (Mart.) Coville for anti-inflammatory activity. Phytotherapy Res 12: 218-220.

Mello JCP, Petereit F, Nahrstedt A 1996a. Flavan-3-ols and prodelphinidins from Stryphnodendron adstringens. Phytochemistry 41: 807-813.

Mello JCP, Petereit F, Nahrstedt A 1996b. Prorobinetinidins from Stryphnodendron adstringens. Phytochemistry 42: 857.

Morgado-Díaz JA, Nakamura CV, Agrellos AO, Diaz WB, Previato JO, Mendonça-Previato L, De Souza W 2001. Isolation and characterization of the Golgi complex of the protozoan Trypanosoma cruzi. Parasitology 123: 33-43.

Panizza S, Rocha AB, Gecchi R, Souza e Silva RAP 1988. Stryphnodendron barbatiman (VELLOZO) MARTIUS: Teor em tanino na casca e sua propriedade cicatizante. Rev Ciências Farmacêuticas 10: 101-106.

Rebecca MA, Ishii-Iwamoto EL, Kelmer-Bracht AM, CaparrozAssef SM, Cuman RKN, Pagadigorria CL, Mello JCP, Bracht A, Bersani-Amado CA 2003. Effect of Stryphnodendron adstringens (barbatimão) on energy metabo- 
lism in the rat liver. Toxicol Letters 143: 55-63.

Roitman I, Roitman C 1972. Increase growth inhibition of trypanosomatidal drugs at $37^{\circ} \mathrm{C}$. J Protozool 19: 59.

Roitman C, Roitman I, Azevedo HP 1972. Growth of an insect trypanosomatid at $37^{\circ} \mathrm{C}$ in a defined medium. J Protozool 19: 346-349.

Santos CAM, Torres KR, Leonart R 1987. Plantas Medicinais. Scientia et Labor, Curitiba.

Santos CS, Mello JCP 2003. Taninos. In CMO Simões, Farmacognosia da Planta ao Medicamento, cap. 24, $5^{\mathrm{a}}$ ed., Ed. Universidade/UFRGS/Ed. da UFSC, Porto Alegre/ Florianópolis, p. 615-656.

Santos CS, Costa WF, Ribeiro JP, Guimarães DO, Ferri PH, Ferreira HD, Seraphin JC 2002. Tannin composition of barbatimão species. Fitoterapia 73: 292-299.
Scalbert A 1991. Antimicrobial properties of tannins. Phytochemistry 30: 3875-3883.

Teixeira ML, Soares AR, Scolforo JRS 1990. Variação do teor de tanino da casca de barbatimão [Stryphnodendron adstringens (Mart. Coville)] em 10 locais de Minas Gerais. Ciências Práticas Lavras 14: 229-232.

Thompson RS, Jacques D, Haslam E, Tanner RJN 1972. Plant proantocyanidins. Parte 1. Introduction; the isolation, structure, and distribution in nature of plant procyanidins. $J$ Cheml Soc Perkin Transl I: 1387.

Toledo CEM 2002. Estudos Anatômico, Químico e Biológico das Cascas e Extratos de Stryphnodendron adstringens (Martius) Coville, Leguminosae, MSc Thesis, Faculdade de Ciências Farmacêuticas, Universidade Estadual Paulista, Araraquara, SP, 92 pp. 